\title{
Sergio Tognetti \\ The development of the Florentine silk industry: \\ a positive response to the crisis of the fourteenth century
}

Estratto da Reti Medievali Rivista, V - 2004/ 2 (luglio-dicembre)

$<$ <ttp://www.storia.unifi.it/_RM/rivista/saggi/Tognetti.htm>

Firenze University Press 


\title{
The development of the Florentine silk industry: a positive response to the crisis of the fourteenth century
}

\author{
di Sergio Tognetti
}

1. When we talk about the 'crisis of the fourteenth century', we are generally referring to a series of phenomena that have almost always been viewed as negative, especially when attention has focused on the evolution of the European economy: recurrent plague epidemics, starting with the one in 1348, which led to a sharp reduction in the urban and rural population; famine; war; the abandonment of villages; the reduction or stagnation of agricultural yields; the growth in wages and hence the cost of labour; the inability of urban economies to respond positively to changes in demand and consumption, and so on.

There are obviously innumerable variants on this sketchy outline of the 'crisis' in the various European contexts. It is now clear that the economic depression was felt more in continental than in Mediterranean Europe, that marginal areas suffered more from the drop in population and in agricultural yields, and that, in general, the economic structure of the more important cities managed to adapt to the drastic changes in the fourteenth century much better than the small and medium-sized urban centres. In many cases the fourteenth century was a period in which the gap in wealth between the various urban and regional economies widened, a period in which a kind of hierarchy of production, and thus an early embryonic international division of labour, was established. ${ }^{1}$

It is not accidental that the 'crisis of the fourteenth century' occurred in communal Italy (the north and central regions of the Italian peninsula) in the context of simplifying the general political situation. Through the political/ military subjection of a series of small and middle-sized urban centres, some large cities with republican regimes (as Venice and Florence) or under dynastic rule (Milan under the Visconti and Ferrara under the Este) or absolute monarchies (Rome under the pope) no longer forged states on the basis of 
urban centres but rather according whole regions. In this way they created the preconditions necessary for valorising better-integrated economies of scale, even if corresponding more or less to the needs and interests of the dominating city. ${ }^{2}$

An illuminating example of this is offered by the serious difficulties faced by many Tuscan cities, such as Siena, Pisa, Arezzo, Pistoia, Prato and San Gimignano, which had once been prosperous centres for trading, banking and artisan activities. This was happening at a time when Florence not only responded in fine fashion to the crisis, but could also, thanks to its accumulated economic resources, afford to finance the growing costs of the wars it undertook to annex much of Tuscany. ${ }^{3}$ This military conquest was accompanied by a series of economic policies to stifle or limit the manufacturing industries of the subject cities under Florentine control. The wool and silk industries in particular - which were the most important and lucrative, the most exportoriented and the ones capable of providing employment in broad sectors of the urban and suburban population - were effectively dismantled, or, in the best of cases, turned over to producing low-quality fabrics that did not represent competition for the textile industries of the capital. Certain niche sectors, on the other hand, were encouraged - shipbuilding and leatherworking in Pisa, the production of cotton fabrics in Arezzo, iron-working in the Pistoia area and papermaking at Colle Valdelsa. ${ }^{4}$

In the period when Tuscany (together with Italy and the rest of Europe) was affected by plague, famine and all the other factors we have already mentioned, Florentine primacy over the whole region was an incontrovertible fact. However, in the early fourteenth century Tuscany was still prevalently polycentric, not only from an economic but also from a political, artistic and cultural point of view. ${ }^{5}$ Florence therefore took advantage of the 'crisis', or rather of the incapacity of the weaker and less flexible economies of the other cities to respond effectively to the difficulties of the second half of the century, to increase the gap between it and its rivals and ultimately to politically subject almost all of them. Naturally, all of this could not have happened if Florence had not in turn taken steps to adapt its economy to the rapid change in the situation and in international demand. One of the most macroscopic aspects of the 'crisis' was in fact the increase in the cost of labour, an inevitable consequence of the drop in population and therefore of available labour, and at the same time the rise in the per capita wealth of the affluent classes, an effect of the concentration of wealth in the hands of a limited number of individuals. If we equal out the money wage levels of masons, manual building workers and farm labourers in the period 1326- 1348 at 100, it can be noted that the money wages in the period 1394- 1430 were respectively 253, 299 and 307 (see Table 1). ${ }^{6}$ The available data for textile workers and artisans are not, unfortunately, sufficient to provide similar statistics; however the wages of the so-called Ciompi (wool workers) cannot have been all that different from what building workers and farm labourers earned; likewise the most skilled wool artisans must have earned similar wages to building masons. 
The result was a reduction in low-quality, labour-intensive production and, conversely, the renewed vigour of activities relating to the manufacturing of top-of-the-range goods where the high labour costs - inevitable if one wanted to find specialized, highly qualified labour - could easily be absorbed.

One aspect of the long-term conversion of the Florentine economy was undoubtedly the establishment, in grand style, of the silk manufacturing industry, which was directed towards producing fine fabrics to meet the growing demand for luxury goods on the European markets. Naturally, the silk industry was only the most glaring aspects of a phenomenon that involved pretty much the whole sector of Florentine artisan manufacturing. Such development would have been impossible if the bedrock structure of its economy - international trade and banking, the privileged sphere of action of the so-called banchi grossi' or merchant banking companies - had not survived.

On the other hand, a similar development also took place in Italy in cities like Lucca, Genoa, Venice, Bologna, Milan - all centres possessing a hardened squadron of merchant-entrepreneurs, ready to adapt themselves to the varying economic conditions and capable of instantly seizing opportunities offered by changes in international demand. But an analogous, though more contained evolution also took place in many other urban settings on the Italian peninsula (I am thinking about capitals of seigniorial states such as Ferrara and Mantua, but also great capitals such as Aragonese and Spanish Naples), to the degree that during the Renaissance, Italy took on the aspect of a 'zone producing luxury goods' within the larger panorama of the European economy. ${ }^{7}$

2. Prior to the Black Death, the population of Florence may have been upwards of 100,000 inhabitants, including the contado (the rural area under its jurisdiction) it was over $400,000 .{ }^{8}$ Given such demographic density, the ideal activity from all points of view was wool manufacturing. Throughout the preindustrial age, wool-working involved a large number of different processes, some of which (for instance, the preparation of fibre for spinning) required a large, relatively unskilled workforce, while the final dyeing and finishing phases were handled by skilled workers. ${ }^{9}$ Some processes were farmed out to rural workers; spinning, for instance, was generally carried out by women in the country villages and suburban areas. ${ }^{10}$ The natural consequence of all this was that labour costs comprised $60-65 \%$ of the overall cost of production for the Florentine wool workshops, notwithstanding the fact that the wool used in Florence was, generally speaking, high-quality (from England, for example) and expensive. ${ }^{11}$ It is clear, then, that it was essential to keep labour costs down. Indeed this area of costs was the only one that could really be reduced, without, that is, resorting to the use of low-quality wool; however, this would have compromised competitiveness on the international marketplace.

The wool business also had the advantage of providing employment, directly or indirectly, to a large number of people belonging to the low and lower-middle classes, both in the city and in the rural villages adjoining the urban centre. In Florence in the 1330s, about one third of the urban population, 
approximately 30,000 people, earned its living from the wool sector. ${ }^{12}$ In the decades of peak population levels, all the Italian communal cities adopted economic policies to encourage wool manufacturing. They had good reason to do so; in fact, it was the best solution both for redistributing wealth to the less well-off classes (and thus for stimulating internal demand) and for maintaining public order by providing employment for the potentially dangerous masses. ${ }^{13}$

The Black Death and successive waves of epidemic decimated the Florentine population just as it did other Italian and European cities. By the time of the Ciompi Revolt in 1378, the population had fallen to about 55,000 inhabitants. The figure obtained from the 1427 catasto was 37,000, a minimum figure that was to rise only in the second half of the fifteenth century. The same fate befell the contado, where the number of inhabitants dropped from around 300,000 at the beginning of the fourteenth century to 104,000 in the 1427 catasto. ${ }^{14}$ Given this prolonged drain on the population, it was already a considerable achievement that the wool industry managed to produce 9-10,000 pieces a year in the 1420s and 1430s, compared to about 30,000 pieces in the early 1370s. ${ }^{15}$ During the same 50- to 60-year-period, in the face of a 30\% drop in the city's population, the overall labour force employed in the wool sector, if compared with the urban trades taken together, fell by $60 \% .{ }^{16}$ The strong growth in wages led to a beneficial increase in consumption on the part of the humble urban classes, which had a considerable effect on the diet of the poorer classes and therefore on agricultural production in the country areas subject to Florence and controlled by city-dwelling landlords. However, the rise in labour costs had negative effects on the wool industry and drove many wool-manufacturers to employ workers on a piecework rather than an hourly basis. This was a response to the demands of a labour force that was much more expensive and harder to find than in the past, and also much less willing to accept the impositions of employers. ${ }^{17}$

In such economic and demographic conditions, the best solution was to divert capital towards high-quality production using top-quality raw materials, where the labour costs would be fitting remuneration for workers and highly specialized craftsmen, as was the case in the silk industry. Initial capital investment in the silk industry in the form of raw materials was decisive. Indeed, although silk workers received considerably higher wages than their counterparts in the wool industry, the impact of labour costs on overall industrial costs was far lower. The decisive factor in raising production costs was the combined effect of the price of silk and the highly prized dyes, which taken together could amount to $65-70 \%$ of the industrial costs. ${ }^{18}$ Squeezing labour costs would therefore have been not only pointless, but also damaging. Indeed, it was risky to depreciate the work of qualified workers, because they were the trade's chief asset, and if they had gone elsewhere they could have favoured competition from other cities.

However, the shift to high-quality production could only be implemented if there was an extensive and experienced class of international-level busi- 
nessmen, accustomed to foreign competition and with expert knowledge of markets for sourcing the raw materials and for selling the finished goods. Naturally this socio-economic class also needed to be a fully fledged part of the city's governing class. This came about in Florence from the second half of the thirteenth century onward.

3. In the early fourteenth century silk manufacturing in Florence was just one of the many activities represented by the Arte di Por Santa Maria, the professional guild that, together with those of the Calimala (foreign cloth importers-exporters) Lana (wool guild), Cambio (merchant bankers), the Medici e Speziali (doctors and apothecaries), the Giudici e Notai (judges and notaries), the Vaiai e pellicciai (furriers) made up the seven main Arti Maggiori of the city. Besides protecting the interests of the setaioli - silk manufacturers and merchants - this corporation also represented a host of other trades ranging from gold and silversmiths to the ritagliatori (retailers of wool, linen and cotton cloth), tailors, haberdashers, armourers, celonai (carpet and blanket traders), etc. No profession was regarded as being particularly more important than the others, and the political weight of the guild was due precisely to the fact that it brought together such a vast and heterogeneous collection of modest entrepreneurial groups. The setaioli had neither a numerical or institutional preponderance, and even their profile as organizers of the city's silk manufacturing must have been fairly low-key. ${ }^{19}$

Things began to change in the second half of the fourteenth century, when the general economic and demographic factors we have already touched on were accompanied by an entirely contingent one - the emigration of entrepreneurs and craftsmen from Lucca towards Genoa, Florence, Bologna and Venice.

As is known, silk manufacturing in Italy (and throughout Europe, with the exception of the territories of the Byzantine Empire) originated in Lucca during the twelfth century. Here, for the first time, silk manufacturing had become a highly profitable activity, managed by the city's rich merchant bankers, who exported their products to the major European markets. Lucca maintained a kind of monopoly on production almost until the beginning of the fourteenth century, jealously guarding the secrets of the trade and prudently ensuring that skilled craftsmen did not emigrate to other cities. ${ }^{20}$ In the second decade of the fourteenth century, however, the violent political conflict between the Guelphs and the Ghibellines undermined the productive equilibrium of Lucca. Factional clashes, political persecution, condemnations to exile first under the Ghibilline lordships of Uguccione della Faggiola (1314-1316) and Castruccio Castracani (1316-1328) and then under Pisan domination (1342-1369), led to the migration of Guelph silk traders and artisans towards the cities of the north and centre of Italy. These exporters of capital and conveyors of knowhow were welcomed with open arms, and frequently given tax incentives and various other kinds of economic assistance. ${ }^{21}$ The most macroscopic example is Venice, where there was a marked acceleration in silk manufacturing in the 
second half of the fourteenth century thanks to the steady injection of entrepreneurs, capital and skilled labour from Lucca. ${ }^{22}$

In Florence this all happened more slowly. Emigrants from Lucca generally preferred to move away from Tuscany, and Venice offered more advantages than other cities. It was the major Italian market for oriental goods, including Persian and Chinese raw silk, and was well-placed to sell silk cloth both in the Mediterranean basin and in continental Europe. Furthermore, there was not, as in Florence, a powerful and flourishing wool industry.

It was not until the recession of the late fourteenth century that Florentine silk manufacturing began to move towards a new phase of development. Statutory reforms in 1404 and 1411 sanctioned the predominance of the goldsmiths and setaioli grossi (the silk merchant entrepreneurs) in the Arte di Por Santa Maria, an unequivocal sign that it was gradually being characterized as an industrial corporation and a political manifestation of economic success. ${ }^{23}$ In response to pressure from the leading silk entrepreneurs, in 1420 the guild began promoting gold-beating, incentivizing the immigration to Florence of skilled artisans from other manufacturing centres. ${ }^{24}$ This made it possible to produce, in Florence, the gold and silver gilt thread and leaf used to decorate and enrich silk cloth (here I'm thinking above all about brocade fabrics) destined for a discerning clientele.

At the beginning of the fifteenth century, silk manufacturing received attention from the deliberative organs of the Florentine Republic and the protection and expansion of the new industry became one of the cornerstones of Florentine economic policy. There were four main areas of intervention: ${ }^{25} 1$ ) the incentivizing of the immigration of skilled labour, generally from Venice, Genoa and Lucca; 2) the impeding of the reverse process in all possible ways, by offering tax remissions, by freezing and cancelling debts, and even by decreeing the death penalty for anyone who emigrated to work in another city; 3) the elimination of all competition within the Florentine state, effectively prohibiting silk manufacturing in the subject cities; 4) the promotion of the cultivation of mulberry trees and silkworm breeding in the Tuscan countryside so as to be less dependant on expensive imported raw materials. Of these objectives only the last one was not fully achieved, despite some modest and partial success. Silkworm breeding only really became well-established in the modern age at the time of the first Medici Grand Dukes. ${ }^{26}$

4. The catasti and city chronicles, company account books and records of contributions made by the Arte di Por Santa Maria to the charitable bodies they patronized (above all, the Spedale degli Innocenti) gives us quite a clear picture of the general evolution of the Florentine silk industry in the fifteenth century. The overall picture is of marked growth, one might even say a boom, in the middle decades of the century.

The number of workshops of the setaioli grossi rose from 33 in 1427 to 50 in 1461- 62 (see Table 2). The only small dip occurred in 1480, but for entirely exceptional and contingent reasons that produced only short-term negative 
effects. ${ }^{27}$ In addition, there were those of the setaioli minuti, who were a cross between an artisan and a retailer trader. They sold cuts of cloth and made ribbon, fringes, tassels, belts, sleeves, silk bags and various other haberdashery items. In 1427 there were 18 such businesses, by 1472 the figure had risen to $24 .^{28}$

The number of brokers in the Arte di Por Santa Maria doubled between 1440 and 1461 from 10 to $20 .^{29}$ The overall value of annual production rose from 233,000 florins in $1436-37$ to 270,000 in 1451-53, 300,000 in 1461-62 and 400,000 in $1490 .{ }^{30}$ At the same time there was a significant increase in the number of gold-beating workshops, rising from an average of 10.7 businesses in 1461-70 to an average of 18.2 in 1491-1500 (see Table 3). There was a sharp increase in the manufacturing capacity of many companies, both in qualitative and quantitative terms, and by the end of the fifteenth century there was much less need to offer incentives to attract skilled craftsmen from elsewhere. Trained gold-leaf craftsmen and weavers of brocade and crimson velvet three widths of pile high were being turned out by the city's numerous artisan workshops. ${ }^{31}$

While in Boccaccio's Florence the large 'proletarianized' workforce made a living by working in the wool industry, the situation at the beginning of the sixteenth century had changed significantly. In a letter dated April 9, 1513, Niccolò Machiavelli pointed out to his friend Francesco Vettori: "As fortune has seen to it that I should know nothing about the art of silk or wool manufacturing, nor of profits or losses, but that I am able to reason about the state, either I must shut up or devote myself to reasoning about this". ${ }^{32}$ It is interesting that ignorance of the basic, indispensable workings of a society entirely devoted to business should make Machiavelli feel at a disadvantage, but what seems to me to be most remarkable is that silk should be mentioned first in this short list of the city's major entrepreneurial activities. Wool manufacturing had certainly not disappeared, indeed it was undergoing a new phase of prosperity, ${ }^{33}$ but the city's productive fabric was now strongly oriented towards the manufacturing and sale of top-of-the-range goods, including richly worked silk and gold-threaded silk cloth. The cost of labour had increased, but so too had the skills and professionalism of the workforce. As a result, Renaissance Florence did not return to the demographic levels of the early fourteenth century, given that the conditions for attracting the immigration of a large number of unskilled labourers no longer existed. Nor were there the social tensions that had culminated in the Ciompi Revolt in the fourteenth century.

5. Success of such proportions would have been inconceivable if Florence's wealthiest citizens had not taken an active and determinant part in the development of Florentine silk manufacturing.

They essentially contributed in three main ways. Firstly, they transferred a large slice of their capital towards the setting up of new silk enterprises, while in the past, if they had to choose a safe and profitable manufacturing sector in which to invest part of their liquid assets, they had always chosen the 
wool business. In 1438, the Medici family holding purchased a silk workshop and invested 4,200 florins. Management of the business was entrusted to two experts, who in turn invested a modest amount of capital, creating an initial overall sum of 5,000 florins. ${ }^{34}$ Another notable example is that of Tommaso Spinelli. After having been in the service of the large mercantile and financial companies of the Alberti family as a general assistant and administrator, he became a prestigious merchant banker in his own right. In 1443-1447, Pope Eugenius IV nominated him depositario generale of the Camera Apostolica, in other words the leading papal banker. He was one of the major importers of Florentine cloth on the Roman market in the 1450s and 60s, and set up a silk business in 1454 with 6,000 florins of capital. Nor did the company fold when Tommaso died in 1471, but was kept going by his inheritors. ${ }^{35}$ Many other prominent noble families traditionally interested in large-scale commerce and international banking - Capponi, Corsini, Gondi, Mannelli, Martelli, Pitti, Portinari, Ridolfi, Salviati, Serristori, Strozzi and so on - threw themselves into the trade from the middle of the century onwards. They did not just invest in silk workshops, but soon became involved in gold-beating as well, which led to dual cost savings. The cloth manufacturing company no longer had to turn to the marketplace in search of gold thread and leaf with which to decorate their cloth, but simply used the sister company. The gold-beating workshop drastically reduced the cost of intermediaries to provide purchasers for their output, given that the majority of its business was conducted with the silk companies belonging to the same entrepreneur. ${ }^{36}$

The example of the Serristori family is particularly emblematic, given that the headquarters of the new silk manufacturing company set up in the middle of the fifteenth century was the same one used in the previous decades to run an important and well-established merchant bank with a branch in Barcelona and numerous correspondents dotted around the main Mediterranean and European cities. ${ }^{37}$ Besides its silk manufacturing company, the Serristori also set up gold-beating workshops and a host of related activities, including a series of limited partnerships operating in Bruges and Lyons and, finally, a merchant company operating in London. ${ }^{38}$ The considerable resources of the new Florentine setaioli and the extraordinary profits to be had in an industry that benefited from constant injections of liquid assets are evidenced by the following straightforward data: between 1477 and 1491 the company capital of the Serristori silk manufacturing company rose from 5,333 large florins to 24,248 large florins. The accumulated profit between 1471 and 1492 amounted to the astronomic sum of 57,688 large florins (see Table 4).

In the second place, while financial capital represented a powerful impulse for the development of Florentine silk manufacturing, a no less important role was played by human capital. The merchant bankers, accustomed as they were to operating on the international markets, had considerable knowledge of the centres for the supply of raw materials and possible markets for the finished products. Wide-ranging commercial brokering had always been one of their main areas of activity. Thanks to a well-established network of agencies and 
foreign correspondents they could generally speaking predict when a market was becoming saturated or vice versa, when the prices of manufactured products, commodities and raw materials were going to increase or decrease, when interest rates were set to rise or fall. J oint ventures, maone trust companies and a whole mass of monopolist cartels frequently enabled them to come up with the best prices. They were also highly expert in transferring funds from one part of Europe to another by means of the bill of exchange. At the international fairs of Geneva and then Lyons, which were fully fledged international clearing houses, Florentine businessmen (together with many other Italian traders) held sway. ${ }^{39}$ It is no accident, then, that the Florentine silk traders channelled their most upmarket products not only towards the major capitals and commercial centres of the period but also towards the fairs of Geneva ${ }^{40}$ and Lyons ${ }^{41}$.

In the space of a few decades, mercantile and banking capital on the one hand, and expert management on the other, revolutionized the structure of Florentine silk manufacturing. What in the past had been a skilled but quantitatively modest craft trade with relatively little entrepreneurial flair, had become a strategic sector of the Florentine economy by the end of the fifteenth century.

The third and final factor is that the merchant bankers who engineered the boom in the silk industry in the fifteenth century belonged to the same social class that managed and shaped the core features of the Florentine Republic's economic policy. I have already outlined the main guide lines of this activity and the results achieved. I would simply like to add that at the end of the 1430 s and the beginning of the 1440s, in an attempt to block the development of rival competition in Siena, the Arte di Por Santa Maria, with the tacit support of the Florentine authorities, organized various plans to bribe Sienese craftsmen to flee to Florence after having set fire to the looms. When this proved only partially effective, the Florentine corporation adopted the tactic of dumping, swamping Siena with Florentine cloth at rock-bottom prices. ${ }^{42}$

6. Between the end of the fifteenth and the beginning of the sixteenth century, the Florentine silk industry was one of the most prosperous in Europe. Top-quality silk and gold-decorated silk cloth were sold in large quantities in Naples, Rome, Valencia, Lisbon, Lyons, Bruges, London, Antwerp, Nuremberg, Frankfurt, Leipzig, Budapest, Constantinople, etc. ${ }^{43}$ At the beginning of the modern age, fine Florentine fabrics - on a par with those of Genoa, Venice, Milan, Bologna, Lucca and so on - were one of the most important Italian export items. Thanks to foreign sales of high-quality goods such as silk cloth, the trading balance of Renaissance Italy was very healthy. ${ }^{44}$ All of this was the result of a progressive adaptation to changes in international consumption and demand following the 'crisis' of the fourteenth century. Focusing on the quality rather than the quantity of goods was one of the objectives pursued and attained by the major urban economies on the Italian peninsula. This model of development was only to decline with the depression 
10 Sergio Tognetti

of the seventeenth century. This really was tragic for the destiny of the Italian economy and society, both in terms of its intensity and the long-term negative effects that followed. 


\section{Note}

* This work was presented as a paper at the conference entitled Medieval Italy I. Transition and transformation in medieval Italy, c. 500-1500, organized by William R. Day J r. (2-3 April 2003, Gonville \& Caius College, University of Cambridge). The issues discussed here in a very concise way are developed much more fully in Sergio Tognetti, Un'industria di lusso al servizio del grande commercio (Florence 2002). I would like to extend special thanks to Bill Day and his wife Fiorella for their generous and friendly hospitality during my stay in Cambridge.

${ }^{1}$ As regards Italy in particular, see the acts of the conference Italia 1350-1450: tra crisi, trasformazione e sviluppo (Pistoia 1993), and also Michele Luzzati, 'La dinamica secolare di un "modello italiano"', in: Storia dell'economia italiana Einaudi, ed. Ruggiero Romano, 3 vols (Turin 199091), vol. 1, 5-114, esp. 63-105; Richard A. Goldthwaite, Wealth and the Demand for Art in Italy 1300-1600 (Baltimore \& London 1993), 11-67; Reinhold C. Mueller, 'Epidemie, crisi e rivolte', in: Storia medievale (Rome 1998), 557-584; Franco Franceschi, 'La crisi del XIV secolo e l'Italia', in: Una giornata con Ruggiero Romano, 25 ottobre 2000, ed. Leandro Perini and Manuel Plana (Florence 2001), 13-22.

${ }^{2}$ For a general approach to this topic, see Stephan R. Epstein, Town and country: economy and institutions in latemedieval Italy', Economic History Review, 46 (1993), 453-477; Idem, 'Regional fairs, institutional innovation, and economic growth in late medieval Europe', Economic History Review, 47 (1994), 459-482.

${ }^{3}$ Between the middle of the Trecento and the first quarter of the Quattrocento Florence gained control over about two-thirds of Tuscany: Prato and Pistoia in 1351, Volterra in 1361, San Miniato in 1370, Arezzo in 1384, Pisa in 1406, Cortona in 1411 and Livorno in 1421.

${ }^{4}$ For more about Florentine dominion and the basically negative consequences produced by Florence's economic policies regarding the subject cities, see Florentine Tuscany. Structures and Practices of Power, ed. William J . Connel \&Andrea Zorzi (Cambridge[England] 2000), and David Herlihy, 'Le relazioni economiche di Firenze con le città soggette nel secolo XV', in: Egemonia fiorentina ed autonomie locali nella Toscana nord-occidentale del primo Rinascimento: vita, arte, cultura (Pistoia 1978), 79-109; Paolo Malanima, 'La formazione di una regione economica: la Toscana nei secoli XIII-XV', Società e storia, 20 (1983), 229-269; Stephan R. Epstein, 'Stato territoriale ed economia regionale nella Toscana del Quattrocento', in: La Toscana al tempo di Lorenzo il Magnifico. Politica Economia Cultura Arte, 3 vols. (Pisa 1996), vol. 3, 869-890; Franco Franceschi, Istituzioni e attività economica a Firenze: considerazioni sul governo del settore industriale (1350-1450)', in: Istituzioni e società in Toscana nell’Età Moderna (Rome 1994), 76-117; Sergio Tognetti, 'Attività industriali e commercio di manufatti nelle città toscane del tardo Medioevo (1250 ca. - 1530 ca.)', Archivio Storico Italiano, 159 (2001), 423-479, esp. 450-479.

${ }^{5}$ See also the acts of the conference La Toscana nel XIV secolo. Caratteri di una civiltà regionale, ed. Sergio Gensini (Pisa 1988); and also, for the more economic aspects, Malanima, 'La formazione di una regione economica', 231-256; Tognetti, 'Attività industriali', 426-433.

${ }^{6}$ Florentine wages are analysed in chronological spans of several decades in order to facilitate the understanding of salary patterns over the long run. Clearly with this procedure one inevitably ends up levelling out the highs and lows which are sometimes dramatic in the short term: for example, after the noted increase in wages in the two decades after the plague of 1348, and before the next more moderate trend towards higher wages in the decades around 1400, there was a modest decline in salaries in terms of real buying power (as opposed to nominal terms) in the 1370s. Here we see a phenomenon that, although almost negligible when analysing the price/ salary dynamic in economic terms by decade, is nevertheless of a certain social-historical importance given that it precedes, and to some extent paves the way for the so-called Ciompi Revolt of 1378 (regarding this, see Charles Marie de La Roncière, Prix et salaires à Florence au XIVe siècle (1280-1380) (Rome 1982), esp., 771-790.

${ }^{7}$ For a thorough survey about this subject, see again Goldthwaite, Wealth and the Demand.

${ }^{8}$ For more on the population of Florence prior to the Black Death, the subject of numerous studies by Fiumi, de La Roncière, Herlihy and Pinto, see the recent article by William R. Day Jr., 'The Population of Florence before the Black Death: Survey and Synthesis', J ournal of Medieval History, 28 (2002), 93-129, esp. 94-111, which examines the status quaestionis and offers a new and original interpretation.

${ }^{9}$ Federigo Melis, 'Gli opifici lanieri toscani dei secoli XIII-XVI', in: Idem, Industria e commercio nella Toscana medievale, ed. Bruno Dini (Florence 1987), 201-211; Paolo Malanima, La decadenza di un'economia cittadina. L'industria di Firenze nei secoli XVI-XVIII (Bologna 1982), 202- 
214; Franco Franceschi, Oltre il «Tumulto». I lavoratori fiorentini dell’Arte della Lana fra Tree Quattrocento (Florence 1993), 33-38, 81-94.

${ }^{10}$ Federigo Melis, 'Sulla disseminazione dell'opificio laniero pratese nel Trecento', in: Idem, Industria e commercio, 308-316.

${ }^{11}$ Federigo Melis, 'La formazione dei costi nell'industria laniera alla fine del Trecento', in: Idem, Industria e commercio, 212-307, esp. 293-294; Malanima, La decadenza, 214-217.

${ }^{12}$ For a study of the establishment of the Florentine wool manufacturing industry in the Trecento, see Hidetoshi Hoshino, L'Arte della lana in Firenze nel basso Medioevo. Il commercio della lana e il mercato dei panni fiorentini nei secoli XIII-XV (Florence 1980), 65-152; Franceschi, Oltre il «Tumulto», 6-12.

${ }^{13}$ Raymond de Roover, Labour Conditions in Florence around 1400: Theory, Policy and Reality', in: Florentine Studies. Politics and Society in Renaissance Florence, ed. Nicolai Rubinstein (London 1968), 277-313, esp. 299; Philip J ones, 'La storia economica. Dalla caduta dell'impero romano al secolo XIV', in: Storia dTtalia Einaudi, ed. Ruggiero Romano \& Corrado Vivanti, vol. 2, (Turin 1974), 1467-1810, esp. 1708, 1765.

${ }^{14}$ David Herlihy \& Christiane Klapisch-Zuber, Les Toscans et leur familles. Une étude du catasto florentin du 1427 (Paris 1978), 171-172; Giuliano Pinto, 'Un quadro d'insieme', in: Idem, Campagne e paesaggi toscani del Medioevo (Florence 2002), 7-73, esp. 58-59.

${ }^{15}$ Hoshino, L'Arte della lana, 199-200, 204-206; Franceschi, Oltre il «Tumulto», 13.

${ }^{16}$ Franceschi, Oltre il «Tumulto», 100-104.

${ }^{17}$ Bruno Dini, T lavoratori dell'Arte della lana a Firenze nel XIV e XV secolo', in: Artigiani e salariati. Il mondo del lavoro nell'Italia dei secoli XII-XV (Pistoia 1981), 27-68, esp. 49-52; Franceschi, Oltre il «Tumulto», 211-220, 328-330.

${ }^{18}$ Paola Massa Piergiovanni, Un'impresa serica genovese della prima metà del Cinquecento (Milan 1974), 151-153, Eadem, Tipologia tecnica e organizzazione economica della manodopera serica in alcune esperienze italiane', in: Eadem, Lineamenti di organizzazione economica in uno stato preindustriale. La repubblica di Genova (Genoa 1995), 261-282, esp. 263-264; Bruno Dini, 'L'industria serica in Italia. Secc. XIII-XV', in: Idem, Saggi su un'economia-mondo. Firenze e l'Italia fra mediterraneo ed Europa (secc. XIII-XVI) (Pisa 1995), 51-85, esp. 74-75; Tognetti, Un'industria di lusso, 89-91, 99-103.

${ }^{19}$ Florence Edler de Roover, L'arte della seta a Firenze nei secoli XIV e XV, ed. Sergio Tognetti (Florence 1999), 6-7.

${ }^{20}$ Florence Edler de Roover, 'Lucchese Silks', Ciba Review, 80 (1950), 2902-2930; Dini, 'L'industria serica', 52-60; Patrizia Mainoni, 'La seta in Italia fra XII e XIII secolo. Migrazioni artigiane e tipologie seriche', in: La seta in Italia dal Medioevo al Seicento. Dal baco al drappo, eds. Luca Molà, Reinhold C. Mueller, Claudio Zanier (Venice 2000), 365-399, esp. 372-377.

${ }^{21}$ Luca Molà, La comunità dei lucchesi a Venezia. Immigrazione eindustria della seta nel tardo Medioevo (Venice 1994), 24-36; Edler de Roover, L'arte della seta, 4-6.

${ }^{22}$ Molà, La comunità dei lucchesi, 66-72, 197-207.

${ }^{23}$ Edler de Roover, L'arte della seta, 9-11.

${ }^{24}$ Bruno Dini, Una manifattura di battiloro nel Quattrocento', in: Idem, Saggi, 87-115, esp. 91-92.

${ }^{25}$ Besides the works cited in note 3, see also Luca Molà, 'Oltre i confini della città. Artigiani e imprenditori della seta fiorentini all'estero', in: Arti fiorentine. La grande storia dell'artigianato, vol. 2: Il Quattrocento, ed. Gloria Fossi \& Franco Franceschi (Florence 1999), 85-107, esp. 99-105; Franco Franceschi, T forestieri e l'industria della seta fiorentina fra Medioevo e Rinascimento', in: La seta in Italia, 401-422. For a comparison with the economic policies of Genoa and Venice, see Paola Massa Piergiovanni, L'arte genovese della seta nella normativa dei XV e XVI secolo (Genoa 1970), 183-198; Luca Molà, The Silk Industry of Renaissance Venice (Baltimore \& London 2000), 29-51.

${ }^{26}$ Judith C. Brown, Pescia nel Rinascimento. All'ombra di Firenze (Pescia 1987), 95-172; Hidetoshi Hoshino, 'La seta in Valdinievole nel basso Medioevo', in: Idem, Industria tessile e commercio internazionale nella Firenze del tardo Medioevo, ed. Franco Franceschi \& Sergio Tognetti (Florence 2001), 165-176; Francesco Battistini, Gelsi, bozzoli e caldaie. L'industria della in Toscana tra città, borghi e campagne (sec. XVI-XVIII) (Florence 1998), 49-69, 101-109. The silk industry was much more developed in the dry-land areas of the Venetian countryside: see Molà, The Silk Industry, 217-260; Edoardo Demo, 'La produzione serica a Verona e Vicenza tra Quattro e Cinquecento', in: La seta in Italia, 305-333; Idem, L'“anima della città". L'industria tessilea Verona e Vicenza (1400-1550) (Milan 2001), 47-57. 
${ }^{27}$ These were reasons relating to the Pazzi Conspiracy in 1478 and the war that broke out between the Florentine Republic and the Aragonese Kingdom of Naples, which was allied with Pope Sixtus IV. In addition to this series of negative events, which closed two of the major outlets for Florentine fabrics, there was a serious cereal crop famine and a plague epidemic, which resulted in the temporary closure of the city's workshops in 1479. For more on this, see: Sergio Tognetti, Il banco Cambini. Affari e mercati di una compagnia mercantile-bancaria nella Firenze del XV secolo (Florence 1999), 303-307; Idem, 'Problemi di vettovagliamento cittadino e misure di politica annonaria a Firenze nel XV secolo (1431-1500)', Archivio Storico Italiano, 157 (1999), 461-490, esp. 437-442. For the effects of the crisis on silk manufacturing, see Dini, 'La ricchezza documentaria', tables 1 and 2, 160 and 168.

${ }^{28}$ Tognetti, 'Un'industria di lusso', 24-25, 27.

${ }^{29}$ Dini, 'La ricchezza documentaria', 163.

${ }^{30}$ Ibidem, 166- 168.

${ }^{31}$ Dini, 'I battilori fiorentini', 158.

32 “Perché la fortuna ha fatto, che non sapendo ragionare né dell'arte della seta, né dell'arte della lana, né dei guadagni né delle perdite, et mi conviene ragionare dello stato, et mi bisogna o botarmi di stare cheto, o ragionare di questo", from Rudolf von Albertini, Firenze dalla Repubblica al Principato. Storia e coscienza politica, (Turin 1970), 45.

${ }^{33}$ Hoshino, L'Arte della lana, chapter 5.

${ }^{34}$ Raymond de Roover, The Rise and Decline of the Medici Bank (1397-1494) (Cambridge [Mass.] 1963), 60-61.

${ }^{35}$ Philip J acks \& William Caferro, The Spinelli of Florence. Fortunes of a Renaissance Merchant Family (Pennsylvania 2001), chapters 2-4 by Caferro.

${ }^{36}$ Richard Goldthwaite, Private Wealth in Renaissance Florence: A Study of Four Families (Princeton 1968), 86-87, 161-162, 169-177, 214-216; Bruno Dini, 'L'economia fiorentina dal 1450 al 1530', in: Idem, Saggi, 187-214, esp. 195-197; Idem, 'Una manifattura di battiloro', 110-114; Idem, 'T battilori fiorentini', 145-158.

37 Sergio Tognetti, Da Figline a Firenze. Ascesa economica e politica della famiglia Serristori (secoli XIV-XVI) (Florence 2003), 77-89, 106-113; Idem, Un'industria di lusso, 49-64.

${ }^{38}$ Tognetti, Da Figline a Firenze, 124-139, 158-163; Idem, Un'industria di lusso, 64-84.

${ }^{39}$ J ean-François Bergier, Genève et l'économie européenne de La Renaissance (Paris 1963); Richard Gascon, Grand commerce et vie urbaine au XVIe siècle. Lyon et ses marchands (environ de 1520 environ de 1580) (Paris 1971).

${ }^{40}$ Florence Edler de Roover, 'Andrea Banchi, Florentine Silk Manufacturer and Merchant in the Fifteenth Century, in: Studies in Medieval and Renaissance History, ed. by William M. Bowsky, vol. III (Lincoln [Nebraska] 1966), 221-285, esp. 264, 266-268; Michele Cassandro, Il libro Giallo della compagnia fiorentina di Antonio della Casa e Simone Guadagni, 1453-54 (Prato 1974), 60, 63-65, 67-71, 74-81, 90-93; Idem, 'Banca e commercio dei fiorentini a Ginevra nel secolo XV', Rivista Storica Svizzera, 26 (1976), 567-611, esp. 593-598; J acks \& Caferro, The Spinelli of Florence', 88-90; Tognetti, Un'industria di lusso, 62-64.

${ }^{41}$ Gascon, Grand commerce, 56-65; Dini, 'L'economia fiorentina', 193-199, 203-207; Tognetti, Un'industria di lusso, 75-77, 88-91, 97-103 and passim.

42 Molà, 'Oltre i confini della città', 99-101.

43 Tognetti, Un'industria di lusso, 36-39.

${ }^{44}$ An up-to-date account of the Italian silk industry in the fifteenth and sixteenth century can be found in Molà, The Silk Industry, 3-19. 
Table 1: Index of some money wages in Florence in the fourteenth and fifteenth century.

\begin{tabular}{|l|l|c|c|c|c|}
\hline \multicolumn{2}{|c|}{ Masons } & \multicolumn{2}{c|}{ Manual building workers } & \multicolumn{2}{c|}{ Farm labourers } \\
\hline $1326-1348$ & 100 & $1326-1346$ & 100 & $1326-1347$ & 100 \\
\hline $1350-1369$ & 239 & $1350-1369$ & 264 & $1350-1369$ & 219 \\
\hline $1371-1393$ & 226 & $1371-1393$ & 269 & $1371-1393$ & 278 \\
\hline $1394-1430$ & 253 & $1394-1430$ & 299 & $1394-1430$ & 307 \\
\hline $1431-1470$ & 247 & $1431-1470$ & 285 & $1434-1469$ & 334 \\
\hline $1471-1500$ & 216 & $1473-1500$ & 268 & $1471-1500$ & 269 \\
\hline
\end{tabular}

Source: Sergio Tognetti, 'Prezzi e salari nella Firenze tardomedievale: un profilo', Archivio Storico Italiano, 153 (1995), 263-333, esp. 333.

Table 2: Number of 'setaioli grossi' workshops

\begin{tabular}{|c|c|c|}
\hline Date & Workshops & Source \\
\hline 1427 & 33 & Edler de Roover, L'arte della seta, 62 \\
\hline $1451-1453$ & 34 & Dini, 'La ricchezza documentaria', $156^{a}$ \\
\hline 1458 & 39 & Dini, 'L'industria serica', 73 \\
\hline $1461-1462$ & 50 & Dini, 'La ricchezza documentaria', 158 \\
\hline 1472 & 49 & Dei, La Cronica, 82, 126-127 ${ }^{\mathrm{b}}$ \\
\hline 1480 & 44 & Bianchi-Grossi, 'Botteghe', $61^{\mathrm{c}}$ \\
\hline
\end{tabular}

a Bruno Dini, 'La ricchezza documentaria per l'arte della seta e l'economia fiorentina del Quattrocento', in: Gli Innocenti e Firenze nei secoli. Un ospedale, un archivio, una città, ed. Lucia Sandri (Florence 1996), 153-178.

b Benedetto Dei, La Cronica. Dall'anno 1400 all'anno 1500, ed. Roberto Barducci (Florence 1985).

' Maria Luisa Bianchi \& Maria Letizia Grossi, 'Botteghe, economia e spazio urbano', in: Arti fiorentine, 27-63.

Table 3: Number of gold-beating workshops in 1461-1500.

\begin{tabular}{|l|r|r|r|r|r|r|l|}
\hline 1461 & 10 & 1471 & 14 & 1481 & 10 & 1491 & 16 \\
\hline 1462 & 11 & 1472 & 17 & 1482 & 10 & 1492 & 17 \\
\hline 1463 & 12 & 1473 & 14 & 1483 & $?$ & 1493 & 20 \\
\hline 1464 & 15 & 1474 & 11 & 1484 & 12 & 1494 & 20 \\
\hline 1465 & 10 & 1475 & 13 & 1485 & 13 & 1495 & 18 \\
\hline 1466 & 9 & 1476 & 12 & 1486 & 14 & 1496 & 18 \\
\hline 1467 & 9 & 1477 & 8 & 1487 & 16 & 1497 & 17 \\
\hline 1468 & 9 & 1478 & 7 & 1488 & 18 & 1498 & 20 \\
\hline 1469 & 8 & 1479 & 9 & 1489 & 19 & 1499 & 20 \\
\hline 1470 & 14 & 1480 & 9 & 1490 & 18 & 1500 & 16 \\
\hline
\end{tabular}

Source: Bruno Dini, 'I battilori fiorentini nel Quattrocento', in: Medioevo Mezzogiorno Mediterraneo. Studi in onore di Mario Del Treppo, ed. Gabriella Rossetti \& Giovanni Vitolo, 2 vols (Naples 2000), vol. 2, 139-161, esp. 145, 152, 154, 157. 
Table 4: Details of the Serristori silk manufacturing company from 25J uly 1470 to 25J uly 1492.

\begin{tabular}{|c|c|c|c|c|}
\hline Date & $\begin{array}{c}\text { Manufactured } \\
\text { silk } \\
\text { (in pounds and } \\
\text { ounces) }\end{array}$ & $\begin{array}{c}\text { Cost of purcha- } \\
\text { sing and manu- } \\
\text { facturing silk, } \\
\text { plus other costs } \\
\text { (in large florins) }\end{array}$ & $\begin{array}{c}\text { Sales revenue } \\
\text { from the sale of } \\
\text { fabrics and from } \\
\text { other activities } \\
\text { (in large florins) }\end{array}$ & $\begin{array}{c}\text { Profits } \\
\text { (in large florins) }\end{array}$ \\
\hline 25.VII.1471 & 3331.06 & 10682.18 .05 & 11941.00 .11 & 1258.02 .06 \\
\hline 25.VII.1472 & 3229.05 & 9064.06 .01 & 10782.10 & 1718.03 .11 \\
\hline 25.VII.1473 & 2847.11 & 7716.19 .07 & 10010.11 .06 & 2293.11 .11 \\
\hline 25.VII.1474 & 2900.07 & 7635.04 .03 & 9169.01 .05 & 1533.17 .02 \\
\hline 25.VII.1475 & 3497.01 & 9611.15 .02 & 11037.09 .08 & 1425.14 .06 \\
\hline 25.VII.1476 & 4575.10 & 12062.06 .02 & 13629.16 .03 & 1567.10 .01 \\
\hline 25.VII.1477 & 3877.10 & 12164.11 .05 & 13823.11 .04 & 1658.19 .11 \\
\hline 25.VII.1478 & 4777.02 & 13353.08 .01 & 15187.18 .11 & 1834.10 .10 \\
\hline 25.VII.1480 & 8257.10 & 22621.03 .07 & 28689.04 .06 & 6068.00 .11 \\
\hline 25.VII.1481 & 6474.01 & 15702.14 .08 & 19335.07 .01 & 3632.12 .05 \\
\hline 25.VII.1482 & 5866.06 & 14557.00 .01 & 19016.07 & 4459.06 .11 \\
\hline 25.VII.1483 & 6249.02 & 16637.05 .11 & 19849.04 .02 & 3211.18 .03 \\
\hline 25.VII.1484 & 6357.07 & 15530.11 .09 & 19127.18 .08 & 3597.06 .11 \\
\hline 25.VII.1485 & 6739.04 & 15967.13 .11 & 19218.10 .07 & 3250.16 .08 \\
\hline 25.VII.1486 & 7146.07 & 17014.03 & 22023.19 .11 & 5009.16 .11 \\
\hline 25.VII.1487 & 8059.05 & 19782.11 & 23390.04 .05 & 3607.13 .05 \\
\hline 25.VII.1488 & 6743.03 & 17197.02 .03 & 19933.17 .01 & 2736.14 .10 \\
\hline 25.VII.1489 & 5499.08 & 14256.05 .07 & 15346.14 .10 & 1090.09 .03 \\
\hline 25.VII.1490 & 6493.05 & 13754.08 .05 & 17701.13 .10 & 3947.05 .05 \\
\hline 25.VII.1491 & 6439.02 & 15457.14 .11 & 17128.08 & 1670.13 .01 \\
\hline 25.VII.1492 & 6172.02 & 16770.00 .01 & 18885.07 .02 & 2115.07 .01 \\
\hline TOTALE & 115535.06 & 297540.04 .04 & 355228.17 .03 & 57688.12 .11 \\
\hline & & & & \\
\hline
\end{tabular}

Source: Archivio di Stato di Firenze, Serristori, 595, fols. 6, 17, 19, 21, 23, 25, 27, 29, 31, 33, 35, 37, $39,41,42,45,46,47,55,57,58,63$. 